\title{
Obstetric outcomes of booked teenage pregnancies at University of Calabar Teaching Hospital, Nigeria
}

This article was published in the following Dove Press journal:

Adolescent Health, Medicine and Therapeutics

24 October 2012

Number of times this article has been viewed

\author{
Boniface Uji Ago \\ Sylvester Abeshi \\ Charles Njoku \\ Thomas Udagbor Agan \\ John Ekabua
}

Department of Obstetrics and

Gynaecology, University of Calabar
Teaching Hospital, Calabar, Nigeria Department of Obstetrics and Gynaecology, University of Calabar

$\mathrm{Tel}+2348023215319$

Fax +23 48I 31246231

Email bonifaceago@yahoo.com
Correspondence: Boniface Uji Ago Teaching Hospital, Calabar, Nigeria

Background: Teenage pregnancy is high-risk and associated with complications due to adverse physiological, anatomical, and socioeconomic factors. The purpose of this study was to determine the patterns and obstetric outcomes of booked teenage pregnancies at the University of Calabar Teaching Hospital (UCTH) in Nigeria.

Methods: A retrospective comparative analysis of teenage pregnancies and mature mothers at UCTH was carried out from January 2011 to December 2011. A total of 82 teenage pregnancies and 72 mature pregnancies were compared.

Results: There were 145 teenage deliveries from a total of 2313 deliveries, ie, $6.3 \%$ of total deliveries. There was no statistically significant difference in the mode of delivery (cesarean section, spontaneous vaginal delivery, instrumental delivery) between the groups of mothers. There was also no difference in risk of complications, including obstructed labor, retained placenta, uterine atony, pre-eclampsia/eclampsia, and antepartum hemorrhage. However, teenage mothers had more perineal lacerations $(P=0.02)$ and more preterm labor $(P=0.05)$, and delivered more low-birth-weight babies $(P=0.02)$.

Conclusion: Supervised teenage pregnancy may not be as hazardous as previously thought.

Keywords: teenage pregnancy, booked pregnancy, obstetric outcome

\section{Introduction}

Teenage pregnancy, which is traditionally defined as pregnancy in female adolescents aged 13-19 years, is universal in all known cultures past and present, with an estimated 14 million teenage girls giving birth to a child every year worldwide. ${ }^{1}$ One in four girls in the world becomes a mother before the age of 19 years. ${ }^{2}$ Sexual activity can occur at an early age, with increased fertility among adolescents. ${ }^{3}$ The factors responsible for these teenage problems include the inherent emphasis on sexual activity in contemporary societies, early sexual maturation with decreasing age at menarche, a breakdown in cultural bonds, lack of parental guidance, and peer pressure. ${ }^{4-6}$

It has long been taught that girls who are immature in height and pelvic size are at risk of complications during pregnancy and delivery, with an overall increase in perinatal loss, ${ }^{7}$ as well as anemia, preterm labor, hypertensive disorders of pregnancy, low-birth-weight babies, and cephalopelvic disproportion, resulting in a high incidence of operative delivery. ${ }^{8}$

The problems of unsafe abortion are common among teenagers. Every year, according to the World Health Organization, an estimated 2.0-2.4 million adolescents resort to abortion. ${ }^{9}$ In comparison with adults, adolescents are more likely to delay the abortion, resort to unskilled persons to perform the procedure, use dangerous methods, and present late when complications arise. ${ }^{10}$ 
In spite of the associated risks of teenage pregnancy, the outcome of pregnancy is improved when there is satisfactory care of the adolescent mother. ${ }^{3,11}$ In fact, with the exception of very young adolescents (younger than 16 years), teenage pregnancy in itself is not biologically harmful. ${ }^{1} \mathrm{~A}$ full-term teenage pregnancy may even constitute the only primary protective factor against breast cancer. ${ }^{1,12}$ The objective of this study was to analyze booked teenage pregnancies managed at the University of Calabar Teaching Hospital (UCTH), particularly with regard to complications during pregnancy and labor, and the outcome of the pregnancies. The aim was to identify complications and compare them with those in mature mothers with a view to early intervention and treatment.

\section{Materials and methods}

This was a retrospective comparative study of all pregnant teenage women aged younger than 20 years and mature mothers aged 20-34 years, booked for antenatal care with pregnancy reaching at least 28 completed weeks, and delivered at UCTH between January 2011 and December 2011. A mature mother was the next woman who delivered after a teenage mother and fulfilled the inclusion criteria. In both groups, exclusion criteria were multiple pregnancy, previous cesarean section, previous uterine surgery, need for cesarean section because of conditions such as cephalopelvic disproportion, gestational diabetes, or insulin-dependent diabetes, and grand multiparity.

Case files for a total of 145 pregnant teenage women were retrieved and analyzed with respect to their age, educational status, pregnancy complications, mode of delivery, delivery complications, and perinatal outcome in terms of Apgar scores at 1 minute, birth weight, and survival up to 1 week of life. Anemia was defined as a packed cell volume of less than $30 \%$ at any stage of pregnancy. Statistical analysis was done using EpiInfo 2004 software (Centers for Disease Control and Prevention, Atlanta, GA).

\section{Results}

There were 2313 total deliveries during the study period. There were 63 unbooked teenage deliveries, which together with 82 booked deliveries gave a total of 145 teenage deliveries, and a prevalence of $6.3 \%$ of all deliveries. Fourteen booked teenagers $(17.1 \%)$ were aged $13-15$ years, 68 (82.9\%) were aged 16-19 years, and the mean age was $17.2 \pm 1.57$ years. Table 1 shows the age distribution of the pregnant teenage mothers, and Table 2 shows that of the mature mothers (73.6\%) were aged 20-29 (mean $26.5 \pm 3.3$ ) years.
Table I Age distribution of teenage mothers at University of Calabar Teaching Hospital, Nigeria

\begin{tabular}{lllll}
\hline $\begin{array}{l}\text { Age } \\
\text { (years) }\end{array}$ & Frequency & Percentage & $\begin{array}{l}\text { Cumulative } \\
\text { percentage }\end{array}$ & $\mathbf{9 5 \%} \mathbf{C l}$ \\
\hline 13 & 1 & 1.2 & 1.2 & $0.0 \%-6.6 \%$ \\
14 & 4 & 4.9 & 6.1 & $1.3 \%-12.0 \%$ \\
15 & 9 & 11.0 & 17.1 & $5.1 \%-19.8 \%$ \\
16 & 11 & 13.4 & 30.5 & $6.9 \%-22.7 \%$ \\
17 & 17 & 20.7 & 51.2 & $12.9 \%-31.1 \%$ \\
18 & 19 & 23.2 & 74.4 & $12.6 \%-31.1 \%$ \\
19 & 21 & 25.6 & 100.0 & $16.6 \%-36.4 \%$ \\
\hline
\end{tabular}

Abbreviation: $\mathrm{Cl}$, confidence interval.

Table 3 compares the educational status, marital status, and parity of the teenagers and mature mothers. More of the teenage mothers had only completed primary and secondary schooling whereas more of the mature mothers had acquired tertiary education $(P<0.05)$. Most of the teenage mothers were unmarried and nulliparous. About $89.0 \%$ of teenagers were nulliparous compared with $30.6 \%$ of mature mothers. Most of the teenagers became pregnant while in secondary school.

Table 4 shows the complications in pregnancy, gestational age at delivery, and mode of delivery. There was no statistically significant difference in the mode of delivery, but there were more deliveries at a gestational age of $<37$ weeks among the teenage mothers $(P=0.05)$.

Table 5 compares complications during delivery and indications for cesarean section. There were no statistically significant differences in the occurrence of obstructed labor, failure to progress in labor, retained placenta, and uterine atony. However, there was a significantly increased risk of perineal laceration in the teenage mothers $(P=0.02)$. There were no statistically significant differences in indications for cesarean section whether due to antepartum hemorrhage, cephalopelvic disproportion, fetal distress, pre-eclampsia/ eclampsia, or breech presentation.

Table 6 show the outcomes of the pregnancies in this study. Significantly more low-birth-weight babies $(<2500 \mathrm{~g})$ were delivered to the teenage mothers; most of them had babies with birth weights of 2500-2999 g, whereas most mature

Table 2 Age distribution of mature mothers at University of Calabar Teaching Hospital, Nigeria

\begin{tabular}{|c|c|c|c|c|}
\hline $\begin{array}{l}\text { Age group } \\
\text { (years, mid- } \\
\text { value } x \text { ) }\end{array}$ & $\begin{array}{l}\text { Frequency, } \\
x(f x)\end{array}$ & Percentage & $\begin{array}{l}\text { Cumulative } \\
\text { percentage }\end{array}$ & $95 \% \mathrm{Cl}$ \\
\hline $20-29(24.5)$ & $53(1298.5)$ & 73.6 & 73.6 & $63.9 \%-84.0 \%$ \\
\hline 30-34 (32) & $19(608)$ & 26.4 & 100.0 & $16.6 \%-36.7 \%$ \\
\hline \multicolumn{5}{|c|}{ Total 72 (I 906.5) mean is Efx/x } \\
\hline
\end{tabular}


Table 3 Educational status, marital status, and parity of teenage and mature mothers

\begin{tabular}{|c|c|c|c|c|c|}
\hline \multirow{2}{*}{$\begin{array}{l}\text { Educational } \\
\text { status }\end{array}$} & \multicolumn{2}{|c|}{ Teenage mother } & \multicolumn{2}{|c|}{ Mature mother } & \multirow[t]{2}{*}{$P$ value } \\
\hline & $n$ & $\%$ & $\mathbf{n}$ & $\%$ & \\
\hline None & - & - & - & - & \\
\hline Primary & 15 & $18.3 \%$ & I & $1.4 \%$ & $0.01 *$ \\
\hline Secondary & 64 & $78.0 \%$ & 40 & $55.6 \%$ & 0.05 \\
\hline Tertiary & 3 & $3.7 \%$ & 31 & $43.0 \%$ & $0.0000000 *$ \\
\hline \multicolumn{6}{|l|}{ Marital status } \\
\hline Married & 31 & $37.8 \%$ & 65 & $90.3 \%$ & $0.0000000 *$ \\
\hline Single & 51 & $62.2 \%$ & 7 & $9.7 \%$ & \\
\hline \multicolumn{6}{|l|}{ Parity } \\
\hline 0 & 73 & $89.0 \%$ & 22 & $30.6 \%$ & $0.0000000 *$ \\
\hline I & 8 & $9.8 \%$ & 27 & $37.5 \%$ & $0.000 I^{*}$ \\
\hline $2-3$ & 1 & $1.2 \%$ & 16 & $22.2 \%$ & $0.000 I^{*}$ \\
\hline 4 & - & - & 7 & $9.7 \%$ & \\
\hline
\end{tabular}

Note: *Statistically significant difference at $P<0.05$.

mothers had babies with birth weights of 3000-3999 g. There were no statistical differences in the Apgar scores at 1 minute and survival at 1 week of life for babies delivered to the two groups of mothers. We identified 14 pregnant teenagers aged 15 years and younger (representing $17.1 \%$ of all booked teenage pregnancies), and 68 aged $16-19$ years (representing 82.9\%). The mean age of the booked teenage mothers was $17.2 \pm 1.57$ years and that of the mature mothers was $26.5 \pm 3.3$ years.

\section{Discussion}

Of a total of 2313 deliveries between January 2011 and December 2011, there were 82 booked and 63 unbooked

Table 4 Complications in pregnancy, gestational age at delivery, and mode of delivery in teenage and mature mothers

\begin{tabular}{|c|c|c|c|c|c|}
\hline \multirow{2}{*}{$\begin{array}{l}\text { Complication } \\
\text { in pregnancy }\end{array}$} & \multicolumn{2}{|c|}{ Teenage mothers } & \multicolumn{2}{|c|}{ Mature mothers } & \multirow[t]{2}{*}{$P$ value } \\
\hline & n & $\%$ & $\mathbf{n}$ & $\%$ & \\
\hline Anemia & 29 & $35.4 \%$ & 5 & $6.9 \%$ & $0.00004 *$ \\
\hline APH & 1 & $1.2 \%$ & 3 & $4.2 \%$ & 1.00 \\
\hline IUFD & 1 & $1.2 \%$ & 3 & $4.2 \%$ & 0.34 \\
\hline $\begin{array}{l}\text { Pre-eclampsia/ } \\
\text { eclampsia }\end{array}$ & 2 & $2.4 \%$ & 1 & $1.4 \%$ & 1.0 \\
\hline Preterm labor & 15 & $18.3 \%$ & 1 & $1.4 \%$ & $0.01 *$ \\
\hline Breech & 2 & $2.4 \%$ & 2 & $2.8 \%$ & 1.0 \\
\hline \multicolumn{6}{|c|}{ Gestational age at delivery } \\
\hline$<37$ weeks & 17 & $20.7 \%$ & 6 & $8.3 \%$ & 0.054 \\
\hline $37-42$ weeks & 65 & $79.3 \%$ & 64 & $88.3 \%$ & 0.16 \\
\hline$>42$ weeks & & & 2 & $2.8 \%$ & \\
\hline \multicolumn{6}{|c|}{ Mode of delivery } \\
\hline Cesarean section & 11 & $13.3 \%$ & 6 & $8.3 \%$ & 0.46 \\
\hline SVD & 68 & $82.9 \%$ & 63 & $87.5 \%$ & 0.57 \\
\hline Breech & 1 & $1.2 \%$ & 2 & $2.8 \%$ & 0.60 \\
\hline Forceps/vacuum & 2 & $2.4 \%$ & 1 & $1.4 \%$ & 1.00 \\
\hline
\end{tabular}

Note: *Statistically significant difference.

Abbreviations: APH, antepartum hemorrhage; IUFD, intrauterine fetal death; SVD, spontaneous vaginal delivery.
Table 5 Complications during delivery and indications for cesarean section in teenage and mature mothers

\begin{tabular}{|c|c|c|c|c|c|}
\hline \multirow{2}{*}{$\begin{array}{l}\text { Complication } \\
\text { of delivery }\end{array}$} & \multicolumn{2}{|c|}{ Teenage mothers } & \multicolumn{2}{|c|}{ Mature mothers } & \multirow[t]{2}{*}{$P$ value } \\
\hline & $\mathbf{n}$ & $\%$ & $\mathbf{n}$ & $\%$ & \\
\hline Obstructed labor & 2 & $2.4 \%$ & 1 & $1.4 \%$ & 1.00 \\
\hline Failure to progress & 5 & $6.1 \%$ & 2 & $2.8 \%$ & 0.40 \\
\hline Retained placenta & 4 & $4.9 \%$ & 3 & $4.1 \%$ & 1.00 \\
\hline Uterine atony & 2 & $2.4 \%$ & I & $1.4 \%$ & 1.00 \\
\hline Perineal laceration & 10 & $12.2 \%$ & 6 & $8.3 \%$ & $0.02 *$ \\
\hline \multicolumn{6}{|c|}{ Indication for cesarean section } \\
\hline APH & I & $1.2 \%$ & 2 & $2.8 \%$ & 0.60 \\
\hline CPD & 4 & $4.9 \%$ & 3 & $3.2 \%$ & 1.00 \\
\hline Fetal distress & 3 & $3.7 \%$ & I & $1.4 \%$ & 0.60 \\
\hline $\begin{array}{l}\text { Pre-eclampsia/ } \\
\text { eclampsia }\end{array}$ & 2 & $2.4 \%$ & - & - & 0.50 \\
\hline Breech & I & $1.2 \%$ & - & - & 1.00 \\
\hline
\end{tabular}

Note: *Statistically significant difference.

Abbreviations: APH, antepartum hemorrhage; CPD, cephalopelvic disproportion.

teenage deliveries. Thus, teenage deliveries comprised $6.3 \%$ of all deliveries during the study period. Most of the research done to date on the outcomes of teenage pregnancy has focused on booked versus unbooked patients. Obstetric risks in the unbooked patient are enormous, and for the pregnant teenager, the risks are further worsened by relative biological, physiological, socioeconomic, and psychological immaturity. The booked patient benefits from focused antenatal care objectives, which although not yet scientifically proven to reduce maternal and fetal morbidity/mortality, ${ }^{13}$ have obvious benefits in terms of risk assessment, correction of modifiable conditions, and boosting the psychological and family preparedness for a new child. Teenage pregnancy, defined as pregnancy occurring in women aged 13-19 years, has been associated with adverse obstetric and perinatal outcomes. ${ }^{6,7}$

Our study shows that teenage pregnancy may not be so hazardous if patients are booked early and benefit from antenatal screening for risk factors, investigation and treatment

Table 6 Outcomes of pregnancy in teenage and mature mothers

\begin{tabular}{|c|c|c|c|c|c|}
\hline & \multicolumn{2}{|c|}{ Teenage mothers } & \multicolumn{2}{|c|}{ Mature mothers } & \multirow[t]{2}{*}{$P$ value } \\
\hline & $\mathrm{n}$ & $\%$ & $\mathbf{n}$ & $\%$ & \\
\hline \multicolumn{6}{|l|}{ Birth weight } \\
\hline$<2500 \mathrm{~g}$ & 16 & $19.5 \%$ & 4 & $5.5 \%$ & $0.02 *$ \\
\hline $2500-2999 \mathrm{~g}$ & 36 & $43.9 \%$ & 10 & $13.9 \%$ & $0.0001 *$ \\
\hline $3000-3999 \mathrm{~g}$ & 30 & $36.6 \%$ & 55 & $76.4 \%$ & $0.000002^{*}$ \\
\hline$\geq 4000 \mathrm{~g}$ & & & 3 & $4.2 \%$ & \\
\hline \multicolumn{6}{|c|}{ Apgar score at I minute } \\
\hline$<7$ & 9 & $11.1 \%$ & 3 & $4.2 \%$ & 0.20 \\
\hline$>7$ & 72 & $88.9 \%$ & 69 & $95.8 \%$ & 0.12 \\
\hline \multicolumn{6}{|c|}{ Survival for the first week of life } \\
\hline Alive & 79 & $96.3 \%$ & 70 & $97.2 \%$ & 1.00 \\
\hline Stillbirth & I & $1.2 \%$ & I & $1.4 \%$ & 1.00 \\
\hline Neonatal death & 2 & $2.4 \%$ & I & $1.2 \%$ & 1.00 \\
\hline
\end{tabular}

Note: *Statistically significant difference. 
of parasitic diseases such as helminthiasis and malaria, and a supervised delivery. The commonest complication of pregnancy in our teenage mothers was anemia, which, in most cases, was corrected before delivery. There was no statistically significant difference between the age groups in the occurrence of hypertensive disease, pre-eclampsia/eclampsia, antepartum hemorrhage, or intrauterine fetal death.

There was no statistically significant difference in the cesarean section rate or instrumental deliveries. This could be accounted for by the tendency for preterm delivery and significantly more lower birth weight babies being born to the teenage mothers. Most of the teenage mothers gave birth to babies weighing 2500-2999 g $(P=0.0001)$. These low birth weights could not be attributed solely to preterm delivery, which occurred in only $20.7 \%$ of the teenage mothers. Teenage mothers and mature mothers had term delivery rates of $79.3 \%$ and $88.3 \%$, respectively. Differences in gestational age at delivery were not statistically significant between the two groups $(P=0.16)$.

Booked teenager labor was supervised by a senior obstetrician. The mature mothers had bigger babies, most weighing 3000-3999 g. The mature mothers had an age range of 20-34 years, but most were aged 20-29 years. Most of their deliveries were conducted by midwives, and senior obstetricians were not involved unless there were complications.

There was no statistically significant difference in perinatal outcome between the mature women versus the teenage women. The perinatal outcome of unbooked teenage pregnancies at our center has recently been published. ${ }^{14}$ In that study, the average duration of labor in booked teenagers was 10.85 hours while that in unbooked teenagers was 23.31 hours. Unbooked teenagers had significantly more operative interventions and a poorer perinatal outcome.

\section{Conclusion}

Supervised teenage pregnancy and delivery may not be as hazardous as previously thought. ${ }^{1}$ The emphasis should still be on public health education, contraception, abstinence, and safer sexual practices, and when pregnancy occurs, spouses and family support groups must ensure appropriate antenatal attendance. Health care providers should treat pregnant teenage women as high risk, and be alert to ensure a favorable pregnancy outcome. Where pregnancy, labor, and the puerperium are supervised, the outcome is favorable. The following strategies may further improve the outcomes of teenage pregnancies:

- Effort should be made to reduce the level of poverty in society, which keeps women away from health care services
- Community education should be provided on the dangers of teenage pregnancy so that perception of the problem could change in this age group

- Female sexuality education and abstinence advocacy programs should be encouraged

- Communication especially road networks and telephone services should be improved so that pregnant teenagers may reach out for timely help

- Antenatal care should be free and accessible to all pregnant women, especially for this group of patients who are mostly dependants; family planning should be made available, accessible, affordable, and acceptable to all women of reproductive age to reduce the incidence of unplanned and unwanted pregnancies to which group these patients are vulnerable; and emergency obstetric care, which is a component of safe motherhood, should be offered free of charge.

\section{Disclosure}

The authors report no conflicts of interest in this work.

\section{References}

1. Miguel Oliveira da Silva. Teenage sexual behaviour and pregnancy: Trends and determinants. In: John Studd (ed). Progress in Obstetrics and Gynaecology. volume 15, Elsevier Science Ltd. 2003; 123-133.

2. UNFPA. World Population Report 1999. Geneva UNFPA 1999.

3. Tadesse E, Niguesie S. Adolescent pregnancies in Addis Ababa. East African Medical Journal. 2000;77(8):431-434.

4. Aboyeji AP. Obstetric outcome of teenage primigravidae in Ilorin. Nigeria Medical Journal. 1997;31(3):56-59.

5. Anate M. Adolescent fertility: A panoramic view of the problems. Nigeria Medical Practitioner. 1993;25:3-9.

6. Jimoh AS, Abdul I. Outcome of teenage pregnancies in Ilorin Nigeria. Tropical Journal Obstet Gynaecol. 2004;21(1):27-31.

7. Adetoro OO. Preventing perinatal mortality in developing countries. In: Okonofua F and Odunsi K (eds). Contemporary Obstetrics and Gynaecology for developing countries. Women's Health and Action Research Center Benin. 2003;658-673.

8. Ogedengbe OK, Otolorin EO, Fabanwo AO. Pregnancy performance of Nigerian women age 16 years and below. Afr J Med Sci. 1987;16:89-95.

9. Darroch JE. Teenage sexual and reproductive behaviour in developed countries: Can more progress be made? Family Planning Perspective. 2001;33:244-250.

10. Olukoya AA, Kaya A, et al. Unsafe abortion in adolescents. Int $J$ Gynaecol Obstet. 2001;75:137-147.

11. Wolkinds SN. Teenage pregnancy. J Roy Soc Med. 1985;7:112-116.

12. Lawson A, Lawson J. Breast Cancer - Can you prevent it? London: McGraw-Hill 1999.

13. Omigbodun AO. Preconception and antenatal care. In: Kwawukume EY, Emuveyan EE (Eds). Comprehensive Obstetrics in the tropics. First edition 2002; $7-14$.

14. Iklaki CU, Inaku JU, Ekabua JE, et al. Perinatal outcome in unbooked teenage pregnancies in the University of Calabar Teaching Hospital. ISRN Obstet Gynaecol 2012. http://www.ncbi.nim.nih.gov/ pmc/article/PMC3316960. www.ncbi.nim.nih.gov/pmc/article/ PMC3316960. 
Adolescent Health, Medicine and Therapeutics

Dovepress

\section{Publish your work in this journal}

Adolescent Health, Medicine and Therapeutics is an international, peer-reviewed, open access journal focusing on health, pathology, and treatment issues specific to the adolescent age group. All aspects of health maintenance, preventative measures and disease treatment interventions are addressed within the journal and practitioners from all disciplines are invited to submit their work as well as healthcare researchers and patient support groups.. The manuscript management system is completely online and includes a very quick and fair peerreview system. Visit http://www.dovepress.com/testimonials.php to read real quotes from published authors.

Submit your manuscript here: http://www.dovepress.com/adolescent-health-medicine-and-therapeutics-journal 